\title{
POLA KOMUNIKASI ANTARA PEMBINA ASRAMA PUTRI DAN SANTRI DI UNIT PEMBINAAN SANTRI (UPS) PONDOK PESANTREN MODERN AL-JUNAIDIYAH BIRU BONE
}

\author{
A. Fajar Awaluddin \\ Institut Agama Islam Negeri Bone \\ fajarcece82@gmail.com
}

\begin{abstract}
Abstrak
Komunikasi merupakan sentral dari segala sesuatu kegiatan yang dilakukan sehari-hari kepada masyarakat, mulai dari perkantoran, pendidikan, pergaulan, penjualan dan lain-lain. Banyak problema-problema yang menyangkut golongan akan dapat ditelusuri, dalam hal tersebut terdapat komunikasi yang buruk karena kemacetan dan hambatan-hambatan komunikasi atau karena tidak ada komunikasi sama sekali. Dalam penulisan jurnal ini akan dibahas permasalahan bagaimana pola komunikasi Pembina asrama dan santri Pondok Pesantren. Fokus dalam penelitian ini adalah pola komunikasi antara Pembina asrama dan santri Pondok Pesantren. Penelitian ini menggunakan metode deskriptif analisis kualitatif yang diperoleh dari hasil wawancara, observasi, dan dokumentasi. Pola komunikasi Pembina asrama dan santri di Unit Pembianaan Santri (UPS) Pondok Pesantren Modern Al-Junaidiyah Biru Bone adalah pembinasantri, santri-pembina dan santri-santri. Penelitian dilakukan dengan pendekatan survey dengan jenis penelitian deskriftif kualitatif. Populasi dalam penelitian ini adalah semua santri asrama Aisyah dan asrama Ummu Salamah Pondo Pesantren Modern Al-Junaidiyah Biru Kabupaten Bone. Besarnya sampel ditetapkan sebanyak 350 santri dengan teknik pengambilan sampel adalah purposive sampling. Adapun metode analisis data yang digunakan adalah regresi linier berganda. Dimana penelitian ini bertujuan untuk mendeskripsikan pola komunikasi antara Pembina asrama dan santri dan mendeskripsikan dat-data yang ada dilapangan tentang pola komunikasi antarra Pembina asrama dan santri.
\end{abstract}

Kata Kunci: Pola komunikasi, Guru, santri, Unit Pembinaan Santri (UPS) PP. Modern AlJunaidiyah Biru Bone. 


\begin{abstract}
Communication is central to everything that activities performed daily to the public, ranging from office, education, relationships, sales and others. Many problems-problems concerning the group will be able to be traced, in the event that there is poor communication due to congestion and communication barriers, or because there is no communication at all. In writing this essay will discuss the problem of how communication patterns of teachers and pupils in schools. The focus in this study is the pattern of communication between teacher and student in the classroom at the Extraordinary Elementary School. This study uses descriptive qualitative analysis obtained from interviews, observation, and documentation. Communication patterns of teachers and pupils in UPS Al-Junaidiyah Biru at Bone Meulaboh is the teacher-student, student-teacher and student-student. This is because the number of students that a little, then take the initiative to collect student teacher in the classroom so that the teacher could total in giving attention to students when teaching and learning process. The pupils so feel free to ask or materials that are less obvious yet well understood and can be used to place teachers outpouring students.
\end{abstract}

Keywords: communication patterns, Teachers, Students, PP. Modern Al-Junaidiyah Biru Bone 


\section{PENDAHULUAN}

Seorang anak lahir didunia dengan kondisi yang berbeda-beda. Setiap anak dilahirkan tidak selalu dalam kondisi yang normal, kategori normal berarti tidak mengalami suatu kendala atau gangguan apapun terhadap kondisi psikis dan fisik anak tersebut, akan tetapi tidak sedikit juga anak yang dilahirkan dalam kondisi abnormal atau mempunyai kelainan pada kondisi anak tersebut seperti autis, down syndrome, hiperaktif, tunarungu, cacat fisik dan lain-lain. ${ }^{1}$

Santri, seperti Muhammad Habib Ghulam Alrasyid, hidup dalam banyak batasan. Sejak bangun pagi, harus beribadah hingga waktu sekolah tiba. Sore hari, mereka disibukkan dengan berbagai kegiatan pondok, lalu mengaji dan belajar di malam hari. Waktu tidur relatif singkat, menu makanan terbatas, dan tinggal dalam ruangan besar berisi belasan santri.

Dalam proses pemberian pengertian kepada manusia dibutuhkan komunikasi yang baik dan mudah dipahami oleh mereka. Melalui proses komunikasi manusia akan mengamati, memperhatikan dan mencatat semua tanggapan yang diberikan oleh pemberi pesan. Dengan komunikasi seseorang pemberi pesan (komunikator) akan menyampaikan informasi, ide, ataupun pemikiran, pengetahuan, konsep dan lain-lain kepada orang lain (komunikan) dengan mengharapkan persamaan persepsi. Sehingga melalui komunikasi manusia akan mendapatkan pengertian tentang yang baik dan yang tidak baik bagi dirinya. Melalui komunikasi anak-anak akan bertambah pengetahuan, pengetahuan, pengertian dan pengalamannya. Hal ini sesuai dengan teori Harolld Lasswell yang menjelaskan komunikasi sebagai penyebarluasan informasi, melakukan persuasi, dan melaksanakan instruksi sehingga di dalam melaksanakan komunikasi dapat terjadi persamaan persepsi, adanya pengetahuan dan behaviour change. ${ }^{2}$

Pendidikan di sini melibatkan komponen-komponen komunikasi, dimana di dalamnya terdapat guru sebagai komunikator, siswa/santri sebagai komunikan, materi pelajaran sebagai pesan dan alat bantu mengajar sebagai media. Sebagaimana pula halnya komunikasi, seorang guru atau mengajar mengharapkan adanya efek yang timbul setelah guru menyampaikan bahan pelajaran di dalam kelas ataupun di asrama. Unit Pembinaan Santri (UPS) merupakan lembaga pendidikan di Pondok Pesantren Modern Al-Junaidiyah Biru Bone yang bertujuan membantu anak-anak yang istimewa untuk memberikan pendidikan keagamaan yang dipadukan dengan system kurikulum nasional.

Dari pengamatan awal atau observasi awal peneliti dapatkan, pola komunikasi antar Pembina asrama dan santri Unit Pembinaan Santri (UPS) di Pondok Pesantren Modern AlJunaidiyah Biru mempunyai hambatan di mana pesan yang disampaikan oleh Pembina asrama (komunikator) tidak sampai kepada santri (komunikan) sehingga pesan tersebut kurang direspon sebagaimana mestinya. Terkadang komunikasi antara Pembina asrama dan santri Unit Pembinaan Santri (UPS) di Pondok Pesantren Modern Al-Junaidiyah Biru bisa terjadi melalui komunikasi verbal maupun non verbal. Uraian yang telah penulis ungkapkan, Dari latar belakang tersebut diatas, maka penulis menetapkan judul penelitian yaitu "Pola Komunikasi Antara

\footnotetext{
${ }^{1}$ Delphie, Dasar-Dasar Public Relation, (Renika Cipta, Jakarta, 2006), h. 1

${ }^{2}$ Jalaludin Rahmat, Ilmu Sosial dan Tantangan Zaman, (Raja Grafindo Persada, Jakarta, 2005), h. 5
} 
Pembina Asrama dan Santri di Unit Pembinaan Santri (UPS) Pondok Pesantren Modern AlJunaidiyah Biru"

\section{KAJIAN PUSTAKA}

Istilah Komunikasi berpangkal pada perkataan latin Communis yang artinya membuat kebersamaan atau membangun kebersamaan antara dua orang atau lebih. Komunikasi juga berasal dari akar kata dalam bahasa latin Communico yang artinya membagi (Cherry dalam Stuart, 1983, h. 46) ${ }^{3}$. Komunikasi merupakan proses yang dilakukan oleh manusia setiap hari dalam melakukan hubungan dengan orang lain. Secara umum dapat dikatakan bahwa tidak ada kehidupan manusia tanpa komunikasi. Sebagai makhluk sosial manusia pasti membutuhkan hubungan dengan orang lain. Setiap individu selalu berkeinginan untuk berkomunikasi dengan orang lain dan sebaliknya individu tersebut juga berkeinginan menerima informasi dari orang lain. Keharusan yang timbul pada manusia untuk bekerjasama dengan orang lain agar dapat mencapai tujuan yang dikehendaki, mengakibatkan dibentuknya organisasi, dalam hal ini perusahaan.

Dengan mengadakan komunikasi, setiap manusia dapat menyampaikan dan mengungkapkan apa yang mereka rasakan, yang diinginkan, dan yang diharapkan. Begitu pula halnya dengan komunikasi antara guru dan murid/santri. Dimana guru sebagai penyampai informasi dan murid/santri sebagai penerima informasi yang diberikan guru.

\section{Tujuan Komunikasi}

Hewitt ${ }^{4}$ menjabarkan tujuan penggunaan proses komunikasi secara spesifik sebagai berikut:

1. Mempelajari atau mengajarkan sesuatu

2. Mempengaruhi perilaku seseorang

3. Mengungkapkan perasaan

4. Menjelaskan perilaku sendiri atau perilaku orang lain

5. Berhubungan dengan orang lain

6. Menyelesaian sebuah masalah

\section{Unsur-unsur Komunikasi}

Komunikasi antar manusia hanya bisa terjadi, jika ada seseorang yang menyampaikan pesan kepada orang lain tujuan tertentu, artinya komunikasi hanya bisa terjadi kalau didukung oleh adanya sumber, pesan, media, penerima, dan efek. Unsur-unsur ini bisa juga disebut komponen atau elemen komunikasi.

1. Sumber, Pengirim pesan (Sender) yang memprakarsai komunikasi. Dalam sebuah organisasi, pengirim adalah seorang yang mencapai informasi, kebutuhan atau keinginan dan sebuah maksud untuk disampaikan satu atau lebih orang.

2. Pesan adalah sesuatu yang disampaikan pengirim kepada penerima. Pesan dapat disampaikan dengan cara tatap muka atau melalui media komunikasi. ${ }^{5}$

\footnotetext{
${ }^{3}$ Cherry, Ilmu Komunikasi, Teori dan Praktek, (PT. Remaja Rosdakarya, Yogyakarta, 1983),h. 46

${ }^{4}$ Hewitt, Pengantar Public Relations, (PT. Raja Grafindo Persada, Jakarta), 1981, h. 82.

${ }^{5}$ Hafied Cangara, Public Relation, (Salemba Empat, Jakarta, 2008), h. 22-24.
} 
3. Saluran (Channel) adalah media pengirim dari satu orang ke orang lain, saluran sering tidak dapat dipisahkan dari pesan. Agar komunikasi efektif dan efisien, saluran harus sesuai dengan pesan. Media massa adalah alat yang digunakan dalam penyampaian pesan dari sumber kepada khalayak (penerima) dengan menggunakan alat-alat komunikasi mekanis seperti surat kabar, film, radio, dan televisi ${ }^{6}$

4. Penerima (Receiver), adalah orang yang inderanya menangkap pesan pengirim. Pesan harus disesuaikan dengan latar belakang penerima. Jika pesan tidak sampai pada penerima, komunikasi tidak terjadi.

5. Pengertian sandi (Decoding), pengartian sandi atau penguraian isi sandi adalah proses penerima menafsirkan pesan dan menterjemahkannya kedalam informasi yang bermakna. Pada umumnya, semakin pengartian sandi penerima sesuai dengan pesan yang dimaksudkan pengirim, semakin efektif komunikasi tersebut.

\section{Metode Komunikasi}

Dalam melaksanakan metode komunikasi ada bermacam metode, sehingga dapat diklasifikasikan sebagai berikut:

1. Komunikasi dipandang dari ada atau tidaknya umpan balik, dapat dibagi menjadi dua yaitu: a. Komunikasi satu arah (One way communication)

Dalam komunikasi ini pengirim mengirim pesannya dan mengharapkan penerima memberikan umpan balik. Komunikasi dipandang dari sudut formalitasnya Dipandang dari sudut formalitasnya komunikasi tersebut dapat dibedakan menjadi dua yaitu :

Pertama, Komunikasi Formil adalah Bentuk komunikasi formil terjadi karena sebab akibat dari adanya garis wewenang dan tanggung jawab yang telah ditetapkan oleh manajemen di dalam struktur organisasi dan uraian jabatan. Kedua, Komunikas informal terbentuk karena adanya hubungan pribadi biasanya terjadi secara spontan sehingga tidak dapat dibubarkan secara formal. b. Komunikasi dipandang dari sudut panjangnya saluran Komuniksi dipandang dari sudut panjangnya saluran harus dilalui, dibagi menjadi dua yaitu :

a. Komunikasi Langsung yaitu dikatakan sebagai komunikasi langsung apabila pengirim dan penerima pesan berhubungan secara langsung.

b. Komunikasi tidak langsung yaitu dikatakan sebagai komunikasi tidak langsung apabila antara pengirim dan penerima pesan tidak berhubungan secara langsung tetapi melaui perantara pihak ketiga.

\footnotetext{
${ }^{6}$ Hafied Cangara, Public Relation, (Salemba Empat, Jakarta, 2008), h. 123-126
} 


\section{Pola Komunikasi}

Menurut Joseph A. Devito Pola Komunikasi dibagi Menjadi beberapa bagian yaitu:

\section{Komunikasi Antar Pribadi}

Komunikasi antar pribadi adalah komunikasi antara orang-orang secara tatap muka, yang memungkinkan setiap pesertanya menangkap reaksi orang lain secara langsung, baik secara verbal maupun nonverbal. Sedangkan menurut Devito dalam Suranto (2011, h. 4) komunikasi antar pribadi adalah penyampaian pesan oleh satu orang dan penerimaan pesan oleh orang lain atau sekelompok kecil orang, dengan berbagai dampaknya dan dengan peluang untuk memberikan umpan balik segera.

2. Komunikasi sebagai aksi (komunikasi satu arah)

Menurut Nana Sudjana (1989, h. 67) dalam komunikasi ini guru berperan sebagai pemberi aksi dan siswa pasif. Ceramah pada dasarnya adalah komunikasi satu arah, atau komunikasi sebagai aksi. Komunikasi jenis ini kurang banyak menghidupkan kegiatan siswa belajar.

3. Komunikasi sebagai interaksi (komunikasi dua arah)

Pada komunikasi ini guru dan siswa dapat berperan sama yaitu pemberi aksi dan penerima aksi, disini sudah terlihat hubungan dua arah, tetapi terbatas pada guru dan siswa secara individual. Antara pelajar satu dengan pelajar lainya tidak ada hubungan. Peserta didik tidak dapat berinterkasi dengan teman lainnya. Komunikasi ini lebih baik dari yang pertama.

4. Komunikasi sebagai transaksi (komunikasi banyak arah)

Komunikasi ini tidak hanya melibatkan interaksi dinamis antara guru dan siswa tetapi juga melibatkkan interaksi yang dinamis antara siswa dengan siswa. Proses belajar mengajar dengan pola komunikasi ini mengarah pada proses pembelajaran yang mengembangkan kegiatan siswa yang optimal, sehingga menumbuhkan siswa belajar aktif. Diskusi dan simulasi merupakan strategi yang dapat mengembangkan komunikasi.

\section{Pengertian Santri}

Santri Santri adalah siswa atau murid yang belajar di pesantren, pada umumnya santri terbagi dalam dua kategori. Pertama santri mukim, yaitu murid-murid yang berasal dari daerah yang jauh dan menetap di pesantren. Kedua santri kolong, yaitu para siswa yang berasal dari desa-desa di sekitar pesantren. Oleh karenanya, hanya seorang santri yang memiliki kesungguhan dan kecerdasan yang diberikan kesempatan untuk belajar di sebuah pesantren besar. ${ }^{7}$ Selain dua istilah santri diatas ada juga istilah "santri kelana" dalam dunia pesantren, santri kelana adalah santri yang selalu berpindah- pindah dari satu pesantren ke pesantren lainnya, hanya untuk memperdalam ilmu pengetahuan Agama. ${ }^{8}$

\footnotetext{
${ }^{7}$ Abdullah Hanif, Masa Depan Pesantren, (Jakarta: Ird Press, 2004), hlm. 31.

${ }^{8}$ Abdullah Hanif, Masa Depan Pesantren, (Jakarta: Ird Press, 2004), hlm. 37.
} 


\section{Unit Pembinaan Santri (UPS)}

Unit Pembinaan Santri (UPS) merupakan lembaga pembinaan terhadap santri yang meliputi layanan-layanan khusus yang menunjang manajemen santri.Layanan-layanan yang dibutuhkan santri di sekolah meliputi :

1. Layanan Bimbingan Konseling (BK)

Layanan BK merupakan proses pemberian bantuan terhadap santri agar perkembangannya optimal sehingga santri bisa mengarahkan dirinya dalam bertindak dan bersikap sesuai dengan tuntutan dan situasi lingkungan sekolah, keluarga dan masyarakat. Layanan Unit Pembinaan Santri (UPS) adalah sesuatu yang vital dalam pondok pesantren. kita tahu sendiri tahu bahwa saat ini kebutuhan akan fungsi Unit Pembinaan Santri (UPS) di pesantren semakin tinggi. Fungsi Unit Pembinaan Santri (UPS) dapat kita simpulkan menjadi beberapa garis besar. Penelusuran minat dan bakat. selain itu, juga sebagai pendamping santri dalam berbagai permasalahan di asrama terutama belajar.

\section{Sebagai Motivasi Santri}

Sebagai motivator disini dapat diketahui seorang pembina harus mampu membangkitkan motivasi para santrinya untuk dapat mencapai atau meraih cita - cita. Dalam perjalanannya motivasi di bagi menjadi dua yaitu intrinsik dan ekstrinsik. Intrinsik adalah motivasi yang berasala dari dalam diri siswa, sedangkan ekstrinsik adalah motivasi yang datang dari luar diri santri. Unit Pembinaan Santri (UPS) dalam hal ini adalah sebagai fasilitator untuk pemberi motivasi bagi setiap anak didiknya.

\section{METODELOGI PENELITIAN}

Metode yang digunakan dalam penelitian ini adalah metode kualitatif. Penelitian ini diharapkan mampu menggambarkan tentang bagaimana pola komunikasi antara pembina dan santri PP. Modern Al-Junaidiyah Biru Bone.

\section{Sumber Data dan Teknik Pengumpulan Data}

\section{Data Primer}

Data Primer adalah pengumpulan data yang dilakukan secara langsung oleh peneliti pada lokasi penelitian. Data primer merupakan data yang diperoleh secara langsung dari objek penelitian baik perorangan, kelompok, donor ganisasi, data primer diperoleh melalui wawancara dan observasi.

2. Data Sekunder

Data Sekunder adalah pengumpulan data yang dilakukan melalui studi pustaka yang terdiri dari:

a. Studi Pustaka

Data Sekunder yaitu data yang didapat langsung berupa data pembina dan santri Unit Pembinaan Santri Pesantren (UPS) Putri Modern Al-Junaidiyah Biru Kabupaten Bone yang 
terdiri dari biografi SDLB dan juga dilengkapi dengan jurnal, studi pustaka, buku dan artikel b. Studi Dokumentasi

Dokumentasi dilakukan dengan memanfaatkan dokumen-dokumen tertulis, yang diperoleh dari buku referensi, internet, makalah, gambar, foto atau tesis yang berhubungan dengan kajian penelitian yang diteliti oleh penulis.

\section{Teknik Penentuan Informan}

Teknik penentuan informan dalam penelitian ini menggunakan Purposif Sampling. Purposif sampling adalah teknik penentuan sampel dengan pertimbangan tertentu. Pemilihan sampel dengan memilih responden yang benar-benar mengetahui atau memiliki kompetensi dengan topik penelitian (Nanang Martono, 2007, h. 71) ${ }^{9}$

\section{Lokasi Penelitian}

Penelitian ini dilakukan pada Pondok Pesantren Modern Al-Junaidiyah Biru Kabupaten Bone. Peneliti memilih tempat ini sebagai lokasi penelitian karena melihat pola komunikasi antara Pembina asrama dan santri Pondok Pesantren Modern Al-Junaidiyah Biru. Untuk pengumpulan data mengenai pola komunikasi antara dilakukan peneliti pada tahun 2018. Penelitian ini dilakukan selama 2 Minggu.

\section{Teknik Pengumpulan data}

Teknik pengumpulan data yang digunakan dalam penelitian ini adalah sebagai berikut:

a. Observasi

Pengumpulan data dengan Observasi. Menurut Sutrisno dalam (Sugiono, 2009, h. 203) mengemukakan observasi adalah suatu proses yang komplek, suatu proses yang tersusun dari berbagai proses biologis dan psikologis. ${ }^{10}$

b. Wawancara mendalam (indepth Intervie)

Wawancara merupakan salah satu teknik pengumpulan data yang dilakukan dengan berhadapan secara langsung dengan yang diwawancarai tetapi dapat juga diberikan daftar pertanyaan dahulu untuk dijawab pada kesempatan lain.

\section{Instrumen Penelitian}

Penelitian yang menggunakan metode kualitatif adalah suatu metode penelitian yang digunakan untuk meneliti pada kondisi obyek yang dialami, maka peneliti adalah sebagai instrument kunci. ${ }^{11}$

\footnotetext{
${ }^{9}$ Nanang Martono, Tekhnik Penelitian, (PT. Remaja Rosdakarya, Yogyakarta, 2007), h. 7

${ }^{10}$ Sugiono, Metode Penelitian Kualitatif, (Eresco, Bandung, 2009), h. 205

${ }^{11}$ Maleong, Metode Penelitian, (Renika Cipta, Jakarta, 2002), h. 4
} 


\section{HASIL PENELITIAN DAN PEMBAHASAN}

\section{Hasil Penelitian}

\section{Pola komunikasi antara pembina dan santri Unit Pembinaan Santri Pesantren (UPS) Putri Modern Al-Junaidiyah Biru Kabupaten Bone}

Berdasarkan hasil wawancara terhadap pembina Unit Pembinaan Santri Pesantren (UPS) Putri Modern Al-Junaidiyah Biru Kabupaten Bone tentang pola komunikasi antara pembina dan santri Unit Pembinaan Santri Pesantren (UPS) Putri Modern Al-Junaidiyah Biru Kabupaten Bone, para pembina mengatakan bisa berkomunikasi dengan para santri ini. Berbagai pola juga diterapkan oleh guru-guru yang mengajar di Unit Pembinaan Santri Pesantren (UPS) Putri Modern Al-Junaidiyah Biru Kabupaten Bone tersebut.

Berikut jawaban tentang pemahaman informan mengenai pola komunikasi antara pembina dan santri Unit Pembinaan Santri Pesantren (UPS) Putri Modern Al-Junaidiyah Biru Kabupaten Bone.

"Betul, saya selalu Berkomunikasi dengan para santri yang telah melakukan pelanggaran ini. Hal ini terjadi baik disaat waktu mengajar maupun diluar jam pelajaran. (wawancara 11 Oktober 2018)".

Begitu juga yang diungkapkan oleh Sumartina salah satu pembina Unit Pembinaan Santri Pesantren (UPS) Putri Modern Al-Junaidiyah Biru Kabupaten Bone..

"Cara Saya berkomunikasi dengan santri yang ada di UPS ini adalah dengan semua rencana pengajaran, pertama kita harus memahami apa yang anak-anak kita dapat lakukan. Kita harus mengobservasi anak itu dan melihat beberapa jenis pelanggaran yang dilakukan oleh anak untuk dikomunikasikan, dan apakah dia menggunakan isyarat gerak tubuh, suara atau kata-kata. Kita juga perlu mengetahui apakah dia mampu untuk memulai komunikasi atas keinginannnya sendiri, atau apakah dia berkomunikasi hanya merespon pertanyaan orang lain"(wawancara 11 Oktober 2018)".

Hal tersebut juga diungkapkan oleh A. Ilmiah Makmur yang juga merupakan Koordinator UPS

"Banyak Pola komunikasi yang saya terapkan, untuk memulai komunikasi dengan santri yang melanggar, kita dapat meminta anak untuk mengemukakan sejumlah jenis pesan yang santri coba untuk komunikasikan. Urutan melakukan ini perlu kita temukan cara yang bisa membuat anak berminat untuk berkomunikasi, baik melalui isyarat ataupun gerak badan" (wawancara 12 Oktober 2018)

Hal senada juga diungkapkan oleh Ridwan Huzaifah selaku Kepala Unit UPS menyatakan Bahwa:

"Saya sangat senang bisa berkomunikasi dengan santri yang masuk dalam pembinaan UPS ini, karena saya sangat ingin membantu mereka dalam menerapkan pembelajaran terutama pembinaan karakter. Mereka juga berhak untuk mendapatkan perhatian sebagaimana yang didapatkan oleh santri-santri lainnya" (wawancara 20 Oktober 2018). 
Berdasarkan Hasil wawancara diatas, maka dapat dipahami bahwa pola komunikasi antara pembina dan santri Unit Pembinaan Santri Pesantren (UPS) Putri Modern Al-Junaidiyah Biru Kabupaten Bone sudah terlaksana dengan baik. Hal ini terlihat dari berbagai cara komunikasi yang diterapkan

guru untuk memperbaiki kualitas dalam proses belajar mengajar yang dilaksanakannya. Dapat dipahami bahwa para pembina yang membimbing di Unit Pembinaan Santri Pesantren (UPS) Putri Modern Al-Junaidiyah Biru Kabupaten Bone sering mengikuti pelatihan-pelatihan yang diselenggarakan oleh Kementerian Agama untuk mengatasi kesulitankesulitan yang timbul dalam pola komunikasi dengan santri yang telah melakukan pelanggaran.

Dari hasil wawancara dapat disimpulkan bahwa pelaksanaan pola komunikasi antara pembina dan santri Unit Pembinaan Santri Pesantren (UPS) Putri Modern Al-Junaidiyah Biru Kabupaten Bone sudah terlaksana dengan baik dan untuk kedepannya juga perlu terus diadakan pelatihan-pelatihan khusus yang diberikan kepada pembina Unit Pembinaan Santri Pesantren (UPS) Putri Modern Al-Junaidiyah Biru Kabupaten Bone guna meningkatkan motivasi pola komunikasi antar pembina dan santri Unit Pembinaan Santri Pesantren (UPS) Putri Modern Al-Junaidiyah Biru Kabupaten Bone yang masih tergolong kurang pembinaan untuk meningkatkan mutu pendidikan serta karakternya.

\section{Hambatan-Hambatan Komunikasi Pembina dan Santri Unit Pembinaan Santri Pesantren (UPS) Putri Modern Al-Junaidiyah Biru Kabupaten Bone.}

Informan A. Asniar selaku pembina Unit Pembinaan Santri Pesantren (UPS) Putri

Modern Al-Junaidiyah Biru Kabupaten Bone. menyatakan sebagai berikut:

"Selama saya membina Di Unit Pembinaan Santri Pesantren (UPS) Putri Modern AlJunaidiyah Biru Kabupaten Bone ini, awalnya saya sedikit mengalami kesulitan untuk berkomikasi dengan santri yang masuk dalam daftar pelanggaran yang ada di pondok, dikarenakan kondisi mental dan karakter mereka yang berbeda beda, akan tetapi saya terus berusaha mempelajari tingkah laku para santri, dan Alhamdulillah sampai hingga saat ini saya tidak mengalami lagi kesulitan yang berarti dalam pola komunikasi saya dengan santrti di Unit Pembinaan Santri Pesantren (UPS) Putri Modern Al-Junaidiyah Biru Kabupaten Bone. ini”" (wawancara 16 Oktober 2018)

Pada Unit Pembinaan Santri Pesantren (UPS) Putri Modern Al-Junaidiyah Biru Kabupaten Bone. pola komunikasi antara guru dan murid sudah berjalan dengan baik dan guru tidak banyak merasakan hambatan-hambatan yang berarti karena para pembina Unit Pembinaan Santri Pesantren (UPS) Putri Modern Al-Junaidiyah Biru Kabupaten Bone. tersebut menerapkan pola komunikasi aksi, interaksi dan transaksi. 


\section{PENUTUP}

Berdasarkan hasil penelitian dan pembahasan yang telah dilakukan mengenai pola komunikasi pembina dan santri Unit Pembinaan Santri Pesantren (UPS) Putri Modern AlJunaidiyah Biru Kabupaten Bone. maka dapat ditarik kesimpulan sebagai berikut:

1. Pola komunikasi antara pembina dan santri Unit Pembinaan Santri Pesantren (UPS) Putri Modern Al-Junaidiyah Biru Kabupaten Bone sudah terlaksana dengan baik. Hal ini terlihat dari berbagai cara komunikasi yang diterapkan guru untuk memperbaiki kualitas dalam proses pembinaan yang dilaksanakannya.

2. Pada Unit Pembinaan Santri Pesantren (UPS) Putri Modern Al-Junaidiyah Biru Kabupaten Bone pola komunikasi antara pembina dan santri sudah berjalan dengan baik dan pembina tidak banyak merasakan hambatan-hambatan yang berarti karena para pembina Unit Pembinaan Santri Pesantren (UPS) Putri Modern Al-Junaidiyah Biru Kabupaten Bone tersebut menerapkan pola komunikasi aksi, interaksi dan transaksi.

\section{DAFTAR PUSTAKA}

Cherry, Ilmu Komunikasi, Teori dan Praktek, PT. Remaja Rosdakarya, Yogyakarta, 1983.

Cresswell, Penelitian Kualitatif, PT. Rosdakarya, Bandung, 1998.

Delphie, Dasar-Dasar Public Relation, Renika Cipta, Jakarta, 2006.

Effendy, Pendidikan Anak Berkebutuhan Khusus, PT. Remaja Rosdakarya, Yogyakarta, 2009.

Hewitt, Pengantar Public Relations, PT. Raja Grafindo Persada, Jakarta, 1981.

Cangara, Hafied. Public Relation, Salemba Empat, Jakarta, 2008.

Rahmat, Jalaludin. Ilmu Sosial dan Tantangan Zaman, Raja Grafindo Persada, Jakarta, 2005.

Maleong, Metode Penelitian, Renika Cipta, Jakarta, 2002.

Martono, Nanang. Tekhnik Penelitian, PT. Remaja Rosdakarya, Yogyakarta, 2007.

Sugiono, Metode Penelitian Kualitatif, Eresco, Bandung, 2009 
